\title{
Bestrijding van hybride mismatches in de Nederlandse vennootschapsbelasting
}

\author{
J.N. Bouwman
}

\section{$1 \quad$ Inleiding}

In deze bijdrage staat de invoering per 1 januari 2020 van een regeling tegen hybride mismatches in de Nederlandse Wet op de vennootschapsbelasting 1969 (Wet implementatie tweede EU-richtlijn antibelastingontwijking (hierna: Wet ATAD 2) ${ }^{1}$ ) centraal. De Wet ATAD 2 is een forse stap in het tegengaan van belastingontwijking in internationale verhoudingen, maar is complex. Daarom rijst de vraag of deze wet begrijpelijk en uitvoerbaar is. In deze bijdrage wordt getracht een antwoord te geven op deze vragen. Om de beantwoording overzichtelijk te houden wordt geen aandacht geschonken aan de bestrijding van hybride mismatches met vaste inrichtingen (juridisch niet-zelfstandige buitenlandse filialen). Weliswaar is de bestrijding van deze mismatches ook onderdeel van de Wet ATAD 2, maar het belang ervan lijkt voor de Nederlandse praktijk beperkt. ${ }^{2}$

Hierna wordt aandacht besteed aan het begrip 'hybride mismatch' (par. 2), de totstandkoming van de Wet ATAD 2 (par. 3), de wijze waarop hybride mismatches worden bestreden (par. 4), een aantal situaties waarin hybride mismatches worden bestreden (par. 5), enkele voor de bestrijding relevante begrippen (par. 6), de documentatieverplichting die in het kader van de Wet ATAD 2 is ingevoerd (par. 7, en de opbrengst van de regeling (par. 8). Ten slotte worden enkele conclusies getrokken omtrent de uitvoerbaarheid van de Wet ATAD 2 (par. 9).

\section{Het begrip 'hybride mismatch'}

In de parlementaire geschiedenis van de Wet ATAD $2^{3}$ wordt een hybride mismatch omschreven als een situatie waarin een belastingvoordeel wordt behaald door gebruik te maken van verschillen tussen vennootschapsbelastingstelsels. Dat voordeel kan zich manifesteren doordat lichamen (rechtspersonen of samenwerkingsverbanden) of financiële instrumenten bij gelijktijdige toepassing van de hiervoor bedoelde belastingstelsels verschillend worden behandeld, oftewel verschillend worden gekwalificeerd (kwalificatieverschillen). Het effect van kwalifica-

1 Wet van 18 december 2019, Stb. 2019, 508.

2 Zie ook Kamerstukken II 2016/17, 25087, nr. 150, https://zoek.officielebekendmakingen.nl/ kst-25087-150.html.

3 Kamerstukken II 2018/19, 35241, nr. 3, p. 3-7. 
tieverschillen kan zijn dat, zonder nadere maatregelen, een vergoeding of betaling (hierna: vergoeding) aftrekbaar is terwijl de corresponderende opbrengst niet in de heffing wordt betrokken (aftrek zonder betrekking in de heffing), of dat een vergoeding dubbel in aftrek wordt genomen (dubbele aftrek). De Wet ATAD 2 is alleen van toepassing indien de hybride mismatch zich voordoet in gelieerde verhoudingen of in een zogenoemde gestructureerde regeling. Een gestructureerde regeling is aan de orde indien een hybride mismatch tussen niet-gelieerde partijen tot stand wordt gebracht en het daaruit voortvloeiende voordeel wordt ingeprijsd' in een regeling die door de partijen is getroffen (zie ook in par. 6.2).

Van een hybride mismatch in de zin van de Wet ATAD 2 is geen sprake bij mismatches die niet het gevolg zijn van kwalificatieverschillen. In dit verband kan worden gedacht aan een situatie waarbij de betaler wel is onderworpen aan een vennootschapsbelasting - en daarom een vergoeding ten laste van belaste winst kan aftrekken -, terwijl de ontvanger niet is onderworpen aan een vennootschapsbelasting, bijvoorbeeld omdat hij daarvan is vrijgesteld. De Wet ATAD 2 is evenmin van toepassing op mismatches die ontstaan als gevolg van verschillende opvattingen van staten bij de berekening van prijzen voor onderlinge transacties tussen in die staten gevestigde gelieerde concernmaatschappijen (verrekenprijzen).

\section{De totstandkoming van de Wet ATAD 2}

De oorsprong van de Wet ATAD 2 is gelegen in het zogenoemde BEPS-project ${ }^{4}$ van de OESO. In het kader van dit project is een reeks rapporten verschenen waarin onder meer diverse mogelijkheden tot belastingontwijking door internationaal opererende bedrijven zijn beschreven en tevens is ingegaan op de bestrijding daarvan. Een van de onderwerpen die in dit verband aan de orde zijn gekomen, is het gebruik van hybride mismatches en het neutraliseren van de effecten daarvan. Dit onderwerp is uitgewerkt in BEPS Action 2.

BEPS Action 2 is vervolgens (ook) door de Europese Unie (hierna: EU) overgenomen en heeft geleid tot de Richtlijn (EU) 2017/952 (ATAD 2), ${ }^{6}$ die op 31 december 2019 in de nationale wetgeving van de lidstaten diende te zijn geïmplementeerd. De in dit verband belangrijkste wijziging heeft in Nederland plaatsgevonden door de invoering van afdeling 2.2A in de Wet op de vennootschapsbelasting

4 BEPS staat voor Base Erosion and Profit Shifting.

5 OECD, Neutralising the effects of hybrid mismatch arrangements, Action 2 - 2015 final report, OECD/G20 Base Erosion and Profit Shifting Project, Parijs: OECD Publishing 2015, http:// dx.doi.org/10.1787/9789264241138-en. In 2017 is nog een aanvulling verschenen. Deze ziet op buitenlandse filialen (vaste inrichtingen): OECD, Neutralising the effects of branch mismatch arrangements, Action 2: inclusive framework on BEPS, OECD/G20 Base Erosion and Profit Shifting Project, Parijs: OECD Publishing 2017, http://dx.doi.org/10.1787/9789264278790-en. Beide rapporten zijn relevant voor de toepassing van de Wet ATAD 2.

6 Richtlijn (EU) 2017/952 van de Raad van 29 mei 2017 tot wijziging van Richtlijn (EU) 2016/1164 wat betreft hybridemismatches met derde landen (PbEU 2017, L 144/1). 
1969 (Wet VPB 1969). ATAD 2 vormt wetgevingstechnisch gezien een uitbreiding van de eerder in werking getreden ATAD 1 (Richtlijn (EU) 2016/1164), ${ }^{7}$ die andere maatregelen bevat tegen belastingontwijking. ATAD 1 is eind 2018 geïmplementeerd en is per 1 januari 2019 in werking getreden. ${ }^{8}$

\section{De wijze waarop hybride mismatches worden bestreden}

De ATAD 2 en de Wet ATAD 2 maken geen einde aan de verschillende kwalificatie van lichamen of financiële instrumenten, maar bestrijden de gevolgen van 'een aftrek zonder betrekking in de heffing' respectievelijk 'een dubbele aftrek'. Bij een aftrek zonder betrekking in de heffing resulteert dat in beginsel in het weigeren van de aftrek bij het lichaam dat de vergoeding in aftrek wil brengen (de zogenoemde primaire regel). Bevindt dit lichaam zich in een lidstaat van de EU, dan zal deze regel steeds worden toegepast, omdat ATAD 2, waarin deze regel is vastgelegd, van toepassing is voor alle lidstaten. Mocht de staat waarin het lichaam is gevestigd geen EU-lidstaat zijn en de primaire regel niet toepassen, dan geldt de zogenoemde 'secundaire regel' als de staat van de ontvanger een lidstaat van de EU is. Deze houdt in dat de vergoeding die niet belast is alsnog wordt belast in de lidstaat van de ontvanger.

De gevolgen van een aftrek zonder betrekking in de heffing kunnen worden geillustreerd aan de hand van twee voorbeelden.

\section{Voorbeeld 1}

D BV, gevestigd in Nederland, heeft een lening opgenomen bij haar moeder M Ltd. M Ltd. is gevestigd in staat A. De lening is voor de toepassing van de Nederlandse vennootschapsbelasting vreemd vermogen. Dit betekent dat de rente over de lening in Nederland bij D BV zonder toepassing van de maatregelen tegen hybride mismatches in aftrek komt. In staat A geldt de lening echter als eigen vermogen en wordt de rente gezien als dividend die in staat $A$ onder een vrijstelling valt. De hierdoor ontstane mismatch wordt door toepassing van de in Nederland geldende primaire regel, die aftrek van de rente verbiedt, tegengegaan. Het eindresultaat is dan dat de rentelast in Nederland niet in aftrek komt en dat de corresponderende rentebate vrijgesteld blijft in staat A.

\section{Voorbeeld 2}

$M$, gevestigd in staat $A$, heeft een lening verstrekt aan haar dochter D. D is gevestigd in staat B. De lening is voor de toepassing van de vennootschapsbelasting van staat A eigen vermogen en valt onder een vrijstelling. Dit betekent dat de rente ontvangen over de lening niet wordt belast in staat $A$. In staat $B$ geldt de lening als vreemd vermogen. Dit betekent dat de rente over de lening in staat B in beginsel in aftrek komt. Daardoor ontstaat een hybride mismatch. Omdat staat B

7 Richtlijn (EU) 2016/1164 van de Raad van 12 juli 2016 tot vaststelling van regels ter bestrijding van belastingontwijkingspraktijken welke rechtstreeks van invloed zijn op de werking van de interne markt (PbEU 2016, L 193/1). 
geen maatregelen heeft genomen tegen hybride mismatches vindt de zogenoemde primaire regel geen toepassing en blijft de aftrek van de rente in staat B in stand. Staat A - aannemende dat deze onder ATAD 2 valt - zal nu op M de secundaire regel toepassen. Dit betekent dat de rente in staat $\mathrm{A}$ alsnog bij $\mathrm{M}$ in de heffing wordt betrokken.

Doet zich een dubbele aftrek voor - twee staten staan aftrek van dezelfde vergoeding toe -, dan gelden ook weer een primaire en secundaire regel. De primaire regel luidt dat de vergoeding in de staat die wordt aangemerkt als de staat van de betaler in aftrek komt en dat de aftrek wordt geweigerd in de andere staat. Mocht de primaire regel niet worden toegepast in de andere staat - deze staat laat toch aftrek toe -, dan moet de aftrek worden geweigerd in de staat van de betaler. De staat van de betaler is de staat waarin de betaalde vergoeding haar oorsprong vindt. Ook de gevolgen van dubbele aftrek laten zich illustreren met een voorbeeld.

\section{Voorbeeld 3}

De moeder van het X-concern, XM Ltd., is gevestigd in staat A. Zij houdt alle aandelen in XD BV, gevestigd in Nederland. XD BV houdt op haar beurt alle aandelen in XK BV, een eveneens in Nederland gevestigde vennootschap. Omdat $\mathrm{XD}$ BV en XK BV een fiscale eenheid zijn aangegaan voor de vennootschapsbelasting worden hun resultaten geconsolideerd en wordt het geconsolideerde resultaat bij XD BV in de vennootschapsbelasting betrokken. XD BV heeft een lening aangetrokken bij een bank, waarover zij een rentevergoeding is verschuldigd. Naast het houden van de aandelen in XK BV en het nakomen van de verplichtingen uit hoofde van de geldlening verricht XD BV geen activiteiten. XK BV drijft een onderneming en behaalt daarmee aanzienlijke winsten die belast zijn voor de vennootschapsbelasting. Door de werking van de fiscale eenheid worden deze winsten toegerekend aan XD BV en kan deze vennootschap de rente over de geldlening in aftrek brengen op deze winsten voor de Nederlandse vennootschapsbelasting.

Het komt in dit voorbeeld - zonder tegenmaatregelen - tot dubbele aftrek van de rente die wordt betaald aan de bank, omdat staat A XD BV (niet XK BV) als transparant ziet. Dit laatste leidt er namelijk toe dat staat A XD BV fiscaalrechtelijk niet als een zelfstandige entiteit ziet en dat voor de belastingwetgeving van staat A de bezittingen en schulden van XD BV worden toegerekend aan haar moeder. In dit geval worden dus het aandelenbezit in KD BV en de lening door staat A toegerekend aan XM Ltd. Dit heeft tot gevolg dat de rente die over de lening moet worden betaald in staat A als rente van XM Ltd. wordt beschouwd en daar voor de vennootschapsbelasting van staat A nog een keer in aftrek mag worden gebracht. Voor de goede orde: de winsten die XK BV behaalt, worden dus niet in staat A in aanmerking genomen. De transparantie geldt alleen voor XD BV.

In deze situatie is sprake van een hybride mismatch, omdat staat $A$ en Nederland XD BV fiscaal verschillend behandelen. Staat A ziet XD BV als transparant, terwijl Nederland XD BV als niet-transparant ziet. De primaire regel schrijft nu voor dat 
staat A de aftrek van de rente die aan de bank wordt betaald weigert, terwijl Nederland de aftrek toestaat. Mocht staat A de aftrek toch toestaan, dan dient Nederland volgens de secundaire regel de aftrek te weigeren.

\section{Situaties waarin hybride mismatches worden bestreden}

\subsection{Inleiding}

In art. 12aa, 12ab, 12ad en 12ae Wet VPB 1969 zijn de situaties omschreven waarin zich hybride mismatches voordoen. Daarbij geldt dat art. 12ab, Wet VPB 1969 ziet op de toepassing van de secundaire regel als zich een aftrek zonder betrekking in de heffing voordoet. Hierna wordt een aantal van de hybride mismatches besproken. Bij de bespreking zal ook worden ingegaan op de wijze waarop deze worden bestreden.

\subsection{Art. 12aa lid 1 onder a Wet VPB 1969}

In art. 12aa lid 1 onder a Wet VPB 1969 is vastgelegd dat niet in aftrek komen: 'vergoedingen (...) uit hoofde van een financieel instrument voor zover die leiden tot een aftrek zonder betrekking in de heffing binnen een redelijke termijn als gevolg van verschillen in de kwalificatie van het instrument of de betalingen uit hoofde ervan'. Deze bepaling betreft dus een uitwerking van de primaire regel. Een voorbeeld van deze mismatch is uitgewerkt in voorbeeld 1, zoals hiervoor opgenomen.

In voorbeeld 1 is duidelijk dat het kwalificatieverschil ertoe leidt dat tegenover de aftrek geen heffing zal staan. De wettekst houdt nog rekening met de mogelijkheid dat zich de situatie voordoet dat niet binnen het tijdvak van de aftrek maar wel binnen een redelijke termijn daarna heffing plaatsvindt (bij de ontvanger). In dat geval wordt de aftrek toch niet geschrapt. In art. 12ac lid 3 Wet VPB 1969 is vastgelegd wat onder een redelijke termijn wordt verstaan. Daarvan is in twee gevallen sprake, namelijk als de vergoeding bij de ontvanger ten minste wordt belast in een tijdvak dat aanvangt binnen twaalf maanden na het belastingtijdvak waarin de vergoeding - behoudens art. 12aa Wet VPB 1969 - in aftrek moet worden gebracht, of als redelijkerwijs de verwachting bestaat dat de vergoeding in een toekomstig tijdvak bij de ontvanger in de belastingheffing wordt betrokken, terwijl met betrekking tot het financiële instrument ${ }^{9}$ zakelijke betalingsvoorwaarden zijn overeengekomen. Onder zakelijke betalingsvoorwaarden worden voorwaarden verstaan die tussen derden zouden zijn overeengekomen (met betrekking tot betalingstermijnen, de hoogte van de rente, de hoogte van de schuld, de looptijd, het aflossingsschema, enzovoort). ${ }^{10}$ Een voorbeeld van het tweede geval doet zich voor als de rente over een achtergestelde lening in het land van de betaler in aanmerking wordt genomen in het jaar waaraan zij bedrijfseconomisch moet worden toegerekend, terwijl zij bij de ontvanger pas in aanmerking wordt 
genomen op het moment van betaling. Aftrek bij de betaler is dan toch mogelijk mits zakelijke voorwaarden zijn overeengekomen.

In voorbeeld 1 was sprake van een geldlening. Uit art. 12ac lid 1 onder e Wet VPB 1969 blijkt dat niet alleen een geldlening kwalificeert als een financieel instrument. De tekst van deze bepaling luidt als volgt: een financieel instrument is 'elk instrument dat leidt tot rendement op een geldlening of daarmee vergelijkbare overeenkomst of op eigen vermogen, alsmede een hybride overdracht'. Onder een geldlening wordt een overeenkomst in de zin van art. 7:129 van het Burgerlijk Wetboek (BW) verstaan. Een daarmee vergelijkbare overeenkomst kan de vorm aannemen van financial lease of huurkoop. ${ }^{11}$ Onder eigen vermogen wordt aandelenkapitaal verstaan, terwijl het begrip 'hybride overdracht' wordt gedefinieerd in art. 12ac lid 1 onder h Wet VPB 1969. Deze bepaling luidt als volgt: 'een overeenkomst voor het overdragen van een financieel instrument waarbij de onderliggende opbrengst van het overgedragen financiële instrument voor belastingdoeleinden van de betrokken staten wordt behandeld alsof deze is verkregen door meer dan een van de partijen bij die overeenkomst'. Van een hybride overdracht is moeilijk een nadere definitie te geven. Vaak gaat het om de overdracht van een (ander) financieel instrument, waarover wordt afgesproken dat het later zal worden geretourneerd aan de oorspronkelijk eigenaar. Een voorbeeld van een hybride overdracht is aan de orde indien een Nederlandse bv een geldlening aangaat met een verbonden buitenlandse crediteur waarbij een door de bv gehouden aandelenpakket in de vorm van een deelneming in de zin van art. 13 Wet VPB 1969 als zekerheid zal dienen. Voor het stellen van de zekerheid wordt de deelneming bij het aangaan van de lening aan de buitenlandse crediteur overgedragen en wordt deze tegen een vooraf vastgestelde prijs bij het einde van de lening weer (terug)overgedragen aan de bv. Deze overdracht heeft een hybride karakter indien zij voor het Nederlandse en buitenlandse belastingrecht verschillend wordt uitgelegd. Zo kan het zijn dat de overdracht voor het Nederlandse belastingrecht niet wordt gezien, ${ }^{12}$ terwijl deze wel in aanmerking wordt genomen door het buitenlandse belastingrecht dat geldt voor de crediteur. Als in dat geval voorts is afgesproken dat het dividend dat gedurende het bestaan van de deelneming wordt uitgekeerd op de deelneming door de crediteur kan worden geïncasseerd maar wordt verrekend met de rente die de bv moet betalen, dan kan een hybride mismatch ontstaan. Deze is aan de orde als de rente die de bv betaalt in Nederland kan worden afgetrokken en de buitenlandse crediteur slechts de rente hoeft aan te geven die hij ontvangt na aftrek van het dividend dat is verrekend met de rente, en het dividend voor de buitenlandse crediteur onbelast is vanwege een in het betrokken buitenland geldende (deelnemings)vrijstelling. In dat geval werkt

11 Zie ook art. 15b lid 6 onder a Wet VPB 1969 en de uitleg die daaraan in Kamerstukken II 2018/19, 35030, nr. 3, p. 39 en Kamerstukken II 2018/19, 35030, nr. 7, p. 41 is gegeven.

12 Dat betekent dat de deelneming voor het Nederlandse belastingrecht nog als een bezitting van de bv wordt gezien. Wordt gedurende het bestaan van de lening een dividend uitgekeerd door de deelneming, dan wordt dit in beginsel in aanmerking genomen bij de bv. Tot belastingheffing over het dividend komt het in Nederland echter niet, omdat de bv aanspraak heeft op de deelnemingsvrijstelling van art. 13 Wet VPB 1969. 
art. 12aa lid 1 onder a Wet VPB 1969 en zal de rente in Nederland niet aftrekbaar zijn, voor zover deze staat tegenover het vrijgestelde deelnemingsdividend in het land van de crediteur.

\subsection{Art. 12aa lid 1 onder $b$ Wet VPB 1969}

Art. 12aa lid 1 onder b Wet VPB 1969 ziet op de figuur waarbij een in Nederland gevestigde belastingplichtige voor de vennootschapsbelasting een vergoeding betaalt aan een in Nederland fiscaal transparante rechtsvorm die niet als transparant wordt aangemerkt in het land waarin een of meer van de participanten in die rechtsvorm zijn gevestigd. Als in deze situatie zonder toepassing van de maatregelen tegen hybride mismatches een situatie ontstaat waarbij sprake is van een aftrek zonder betrekking in de heffing, is art. 12aa lid 1 onder b Wet VPB 1969 van toepassing. Dat betekent dat de aftrek van de vergoeding in Nederland wordt geweigerd. Ook in dit geval is dus sprake van een kwalificatieverschil: het lichaam waaraan wordt betaald, wordt voor het belastingrecht van de ene staat anders behandeld dan voor het belastingrecht van de andere staat.

Onder het voorgaande valt ook de zogenoemde cv/bv-structuur. Deze structuur was lange tijd populair bij concerns met een hoofdvestiging in de VS en stelde hen in staat om rente- en royaltybetalingen van bijvoorbeeld hun buiten de VS gelegen concernonderdelen te stallen in een cv die noch in Nederland, noch in de VS werd belast. In Nederland werd geen belasting geheven omdat de cv in Nederland als transparant gold en geldt en de deelgenoten in de cv niet in Nederland waren gevestigd. De cv werd in de VS niet belast omdat zij voor de VS fiscaalrechtelijk als een zelfstandige entiteit werd gezien die niet in de VS was gevestigd. Daarmee miste de VS het noodzakelijke aanknopingspunt om de cv te belasten. Het voorgaande kan worden geillustreerd aan de hand van de volgende structuur en het hierna opgenomen voorbeeld waarin royalty's worden betaald (maar het zou ook rente kunnen betreffen; zie figuur 1 ). 


\section{Voorbeeld 4}

\section{Figuur $1 \quad C v / b v$-structuur}

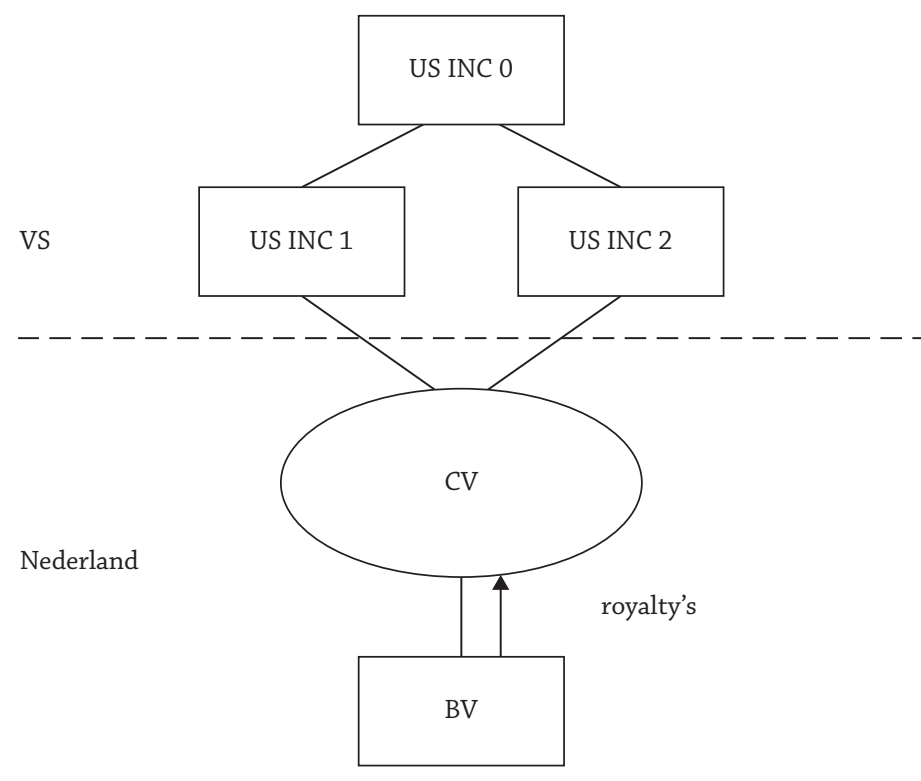

Zonder toepassing van art. 12aa lid 1 onder b Wet VPB 1969 zijn in een structuur als deze de royalty's in Nederland aftrekbaar en kan de Nederlandse bv als doorgeefluik fungeren voor royalty's die elders binnen het concern verschuldigd raken op basis van licenties waaraan (indirect) een intellectueel eigendomsrecht ten grondslag ligt dat door de $\mathrm{cv}$ wordt gehouden. In dat geval zal de bv dus royalty's ontvangen van andere concernonderdelen waartegenover royalty's staan die worden betaald aan de cv. Dit betekent dat er nauwelijks winst zal worden geconstateerd bij de bv.

Art. 12aa lid 1 onder b Wet VPB 1969 is van toepassing indien - zonder toepassing van deze bepaling - sprake is van een aftrek zonder betrekking in de heffing. Anders dan bij onderdeel a ontbreekt hier de toevoeging van een redelijke termijn. Dat betekent dat de vraag of heffing plaatsvindt, moet worden beantwoord voor het tijdvak waarin de aftrek zou plaatsvinden als art. 12aa lid 1 onder b Wet VPB 1969 geen toepassing zou vinden. In de cv/bv-structuur is geen sprake van heffing in het tijdvak van de aftrek omdat noch de VS, noch Nederland de royalty's bij de cv dan in de heffing betrekt. Het feit dat de cv op een later moment de door haar genoten royalty's uitkeert aan haar participanten, terwijl deze opbrengst vervolgens bij hen wordt belast (in de VS), doet aan het voorgaande niet af.

Het door de invoering van ATAD 2 onaantrekkelijk maken van de cv/bv-structuur lijkt voor Nederland meer dan een formaliteit. Uit een impact assessment uit 
2016, zoals dat wordt aangehaald in de parlementaire geschiedenis, ${ }^{13}$ blijkt 'dat er ongeveer 77.600 banen zijn bij bedrijven waar de mogelijkheid tot de cv/bv-structuur een rol gespeeld heeft bij hun keuze voor Nederland'. De vraag is of deze banen op de tocht zijn komen te staan door de invoering van de maatregelen tegen hybride mismatches. Voor iets minder dan de helft van de hiervoor genoemde banen lijkt dit op te kunnen gaan, aldus het impact assessment, maar de regering verwacht dat de gevolgen voor de werkgelegenheid beperkt blijven. Zij benadrukt daarbij in de parlementaire geschiedenis dat zij blijft inzetten op het aantrekkelijk houden van Nederland als vestigingsland, onder meer 'door het tarief in de vennootschapsbelasting stapsgewijs te verlagen van $25 \%$ naar 20,5\%'. Dit laatste voornemen is inmiddels, zo blijkt uit de stukken van Prinsjesdag $2020,{ }^{14}$ komen te vervallen.

Ten slotte. De cv genoemd in het voorbeeld wordt ook wel een omgekeerde hybride genoemd. Deze term is gereserveerd voor een lichaam dat in Nederland transparant is, maar dat in het land (of in de landen) waar de meerderheid van de participanten zich bevindt als niet-transparant wordt beschouwd. Voor een dergelijk lichaam geldt dat het met ingang van 1 januari 2022 als binnenlandse belastingplichtige wordt aangemerkt voor de vennootschapsbelasting als deze in Nederland is opgericht, gevestigd of geregistreerd (art. 2 Wet VPB 1969). Dat betekent dat voor de omgekeerde hybride de mismatches worden weggenomen en dat art. 12aa en 12ab Wet VPB 1969 geen toepassing meer zullen vinden. Het in de vennootschapsbelasting betrekken van de omgekeerde hybride betekent overigens niet alleen dat de aan deze hybride betaalde vergoedingen als bedoeld in art. 12aa en 12ab Wet VPB 1969 in de heffing worden betrokken, maar dat ook de rest van de winst die aan de hybride kan worden toegerekend bij haar in Nederland met vennootschapsbelasting wordt belast. Overigens zijn ook aan deze nog in te voeren belastingplicht nadere complicaties verbonden. Deze zullen hier niet worden besproken. ${ }^{15}$

\subsection{Art. 12aa lid 1 onder c, d en $f$ Wet VPB 1969}

In art. 12aa lid 1 onder c, d en f Wet VPB 1969 zijn maatregelen opgenomen tegen hybride mismatches met vaste inrichtingen. Zoals hiervoor is aangegeven, zullen deze mismatches in dit artikel niet nader worden besproken.

\subsection{Art. 12aa lid 1 onder e Wet VPB 1969}

Art. 12aa lid 1 onder e Wet VPB 1969 verbiedt de aftrek van een vergoeding door een hybride lichaam als die vergoeding in de staat van de ontvanger niet in aanmerking wordt genomen. Een voorbeeld doet zich voor indien een Nederlandse vennootschap een rentebetaling doet aan haar moeder gevestigd in een jurisdictie die de Nederlandse bv als transparant ziet. In dat geval zal de bv de rente in Nederland in aftrek kunnen brengen, terwijl de rente niet wordt waargenomen bij

13 Kamerstukken II 2018/19, 35241, nr. 3, p. 10.

14 Art. XXVI onder B en XXXVII van het Belastingplan 2021 (Kamerstukken II 2020/21, 35572).

15 Zie voor meer informatie Kamerstukken II 2018/19, 35241, nr. 3, p. 38 en 39 en Kamerstukken II 2019/20, 35241, nr. 7, p. 32-35. 
de moeder (voor de moeder betreft het bezien vanuit de staat van de moeder een betaling die niet bestaat). Zonder toepassing van art. 12aa lid 1 onder e Wet VPB 1969 betekent dit dus dat er sprake is van een aftrek zonder betrekking in de heffing.

In Nederland kwam deze figuur in de verhouding met de VS wel voor vanwege de in de VS van toepassing zijnde 'check the box'-regeling. De check-the-box-regeling kwam hiervoor in voorbeeld $3 \mathrm{al}$ aan de orde en houdt kort gezegd in dat een Amerikaanse moeder ervoor kan kiezen haar onmiddellijke dochter voor de Amerikaanse belastingwetgeving als transparant te zien.

Om de check-the-box-regeling vanuit Nederlands perspectief optimaal te benutten was ook voor de figuur van art. 12aa lid 1 onder e Wet VPB 1969 weer van belang dat de Nederlands bv met een eigen Nederlandse dochter een fiscale eenheid aanging, waarin (positieve) winst werd behaald die niet aan de Amerikaanse moeder werd toegerekend in de VS, maar die in Nederland kon worden gebruikt als basis waarop de rente in aftrek kwam. Het hierna opgenomen voorbeeld verduidelijkt het voorgaande (zie figuur 2).

\section{Voorbeeld 5}

\section{Figuur 2 Check-the-box-structuur}

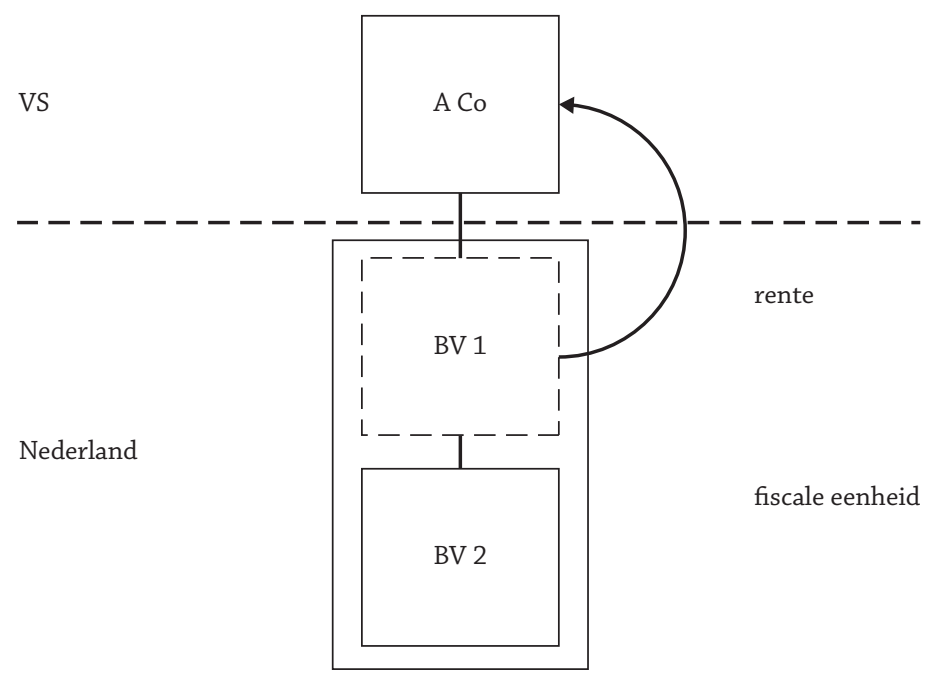

Als de rente $€ 500$ en de winst van BV $2 € 750$ zou hebben bedragen, was de uitkomst zonder toepassing van art. 12aa lid 1 onder e Wet VPB 1969 dat in Nederland $€ 250$ was belast, terwijl in de VS geen belast voordeel van $€ 500$ werd genoteerd. Toepassing van art. 12aa lid 1 onder e Wet VPB 1969 betekent dat in Nederland toch over $€ 750$ belasting wordt betaald, omdat de rente niet in aftrek komt. 
De transparantie van een vennootschap als BV 1 in het hiervoor opgenomen voorbeeld kan tot gevolg hebben dat sprake is van zogenoemd 'dubbel in aanmerking genomen inkomen'. Dit doet zich voor indien BV 1 - naast de rentekosten eigen (positieve) voordelen (inkomsten) geniet. Bij deze inkomsten werkt de transparantie namelijk zo uit dat deze zowel binnen de Nederlandse fiscale eenheid moeten worden verantwoord als bij A Co. In deze situatie zullen de inkomsten van BV 1 dus én in Nederland én in de VS in de heffing worden betrokken. Hoewel in de praktijk door belastingplichtigen maatregelen werden genomen om deze situatie te vermijden, is ter zake door de wetgever in combinatie met de bestrijding van de hybride mismatch van art. 12aa lid 1 onder e Wet VPB 1969 toch een voorziening getroffen in art. 12aa lid 3 en 12af Wet VPB 1969, die overkill door eerstgenoemde bepaling moet voorkomen.

Art. 12aa lid 3 Wet VPB 1969 ziet op het jaar waarin de vergoeding (de rentekosten uit het voorbeeld) wordt betaald en legt vast dat de vergoeding in Nederland - ondanks art. 12aa lid 1 onder e Wet VPB 1969 - toch in aftrek komt, voor zover deze in hetzelfde jaar op dubbel in aanmerking genomen inkomen in mindering valt te brengen. Vertaald naar het hiervoor opgenomen voorbeeld betekent dit dat van de rentebetaling van $€ 500$ toch $€ 300$ in aftrek komt indien BV $1 € 300$ aan inkomsten geniet die zowel in Nederland als in de VS tot de winst worden gerekend. ${ }^{16}$ Dat betekent dan dat de aftrek uiteindelijk wordt geweigerd tot een bedrag van $€ 200$.

Laatstgenoemde weigering kan met toepassing van art. 12af Wet VPB 1969 feitelijk ongedaan worden gemaakt in een volgend jaar, als zich in dat jaar weer dubbel in aanmerking genomen inkomen aandient. Tot het bedrag van de eerder in aftrek geweigerde vergoeding wordt dan bij de bepaling van de winst van BV 1 in Nederland het dubbel in aanmerking genomen inkomen in aftrek toegelaten. Als het eerdere voorbeeld nog wordt uitgebreid en er zich in het volgende jaar bij BV 1 nog dubbel in aanmerking genomen inkomen voordoet tot een bedrag van $€ 250$, dan wordt met toepassing van art. 12af Wet VPB $1969 € 200$ van dit voordeel niet in de heffing van de vennootschapsbelasting betrokken. Voor de resterende $€ 50$ aan dubbel inkomen wordt in Nederland geen tegemoetkoming geboden.

\subsection{Art. 12aa lid 1 onder $g$ Wet VPB 1969}

In art. 12aa lid 1 onder $g$ Wet VPB 1969 is vastgelegd dat niet in aftrek komen 'vergoedingen, betalingen, lasten of verliezen voor zover die leiden tot een dubbele aftrek'. Het meest aansprekende voorbeeld dat bij deze bepaling hoort, is het hiervoor opgenomen voorbeeld 3 . In dit voorbeeld deed zich de situatie voor dat een in Nederland gevestigde dochter-bv door de staat waar haar onmiddellijke moeder was gevestigd als transparant werd gezien, met als consequentie dat 
zonder toepassing van art. 12aa lid 1 onder g Wet VPB 1969 de rente die door de bv werd betaald aan een derde niet alleen in Nederland, maar ook in de staat van de moeder ten laste van de winst kwam.

Technisch gesproken vertoont de bepaling enige gelijkenis met art. 12aa lid 1 onder e Wet VPB 1969. Dat betekent dat ook hier geldt dat toch aftrek mogelijk is, voor zover de vergoeding in mindering op dubbel in aanmerking gekomen inkomen komt (art. 12aa lid 3 en 12af Wet VPB 1969). Een element waarin art. 12aa lid 1 onder g Wet VPB 1969 afwijkt van de hiervoor behandelde bepalingen tegen hybride mismatches is dat naast betalingen en vergoedingen ook lasten en verliezen bij toepassing van de bepaling van aftrek worden uitgesloten. Bij lasten en verliezen gaat het om afschrijvingen en afwaarderingsverliezen.

\subsection{Art. 12ad Wet VPB 1969}

Art. 12ad Wet VPB 1969 richt zich tegen de zogenoemde geïmporteerde hybride mismatch. Deze situatie is aan de orde als een vergoeding die wordt betaald door een Nederlandse belastingplichtige bij de gelieerde ontvanger wordt gebruikt voor de betaling van een vergoeding aan een andere gelieerde ontvanger met wie een hybride mismatch ontstaat. Dit kan worden geïllustreerd met een voorbeeld (figuur 3).

\section{Voorbeeld 6}

\section{Figuur 3 Geïmporteerde-hybride-mismatch-structuur}

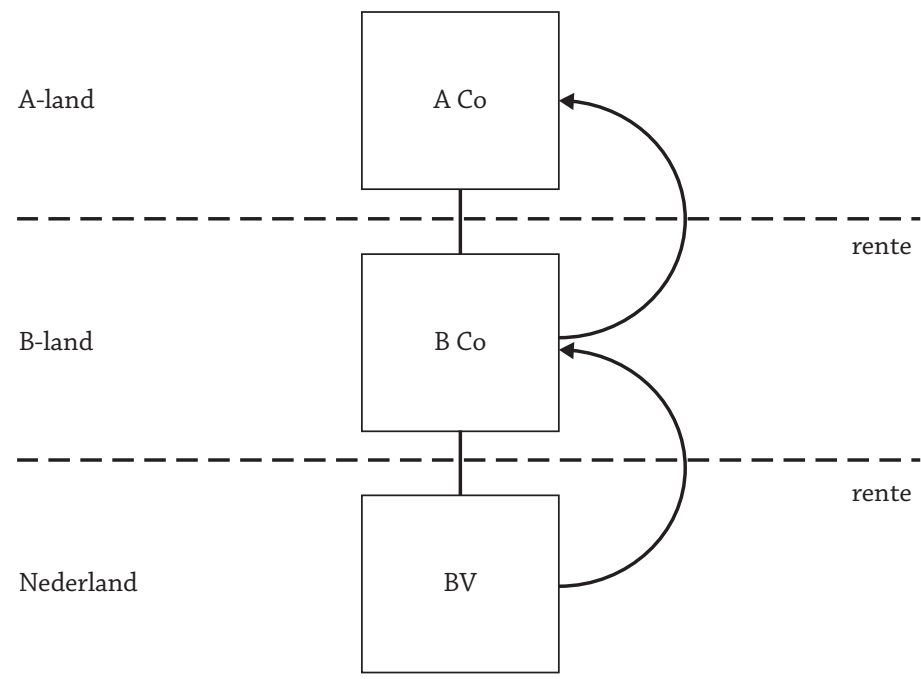

In dit voorbeeld wordt de rente die BV aan B Co betaalt, gebruikt voor een betaling op een hybride financieel instrument door B Co aan A Co. De betaling door B Co is in staat B aftrekbaar en in staat A onbelast, omdat staat A het financieel instrument als eigen vermogen ziet, terwijl staat $B$ het instrument als vreemd vermogen ziet. Omdat de hybride mismatch niet wordt bestreden in staat B en 
evenmin in staat A, komt het tot toepassing van art. 12ad lid 1 Wet VPB 1969 en wordt aftrek van de rente in Nederland bij BV geweigerd.

Voor de aanwezigheid van een hybride mismatch is het niet nodig dat de mismatch al optreedt tussen de twee schakels die zich onmiddellijk boven de Nederlandse BV bevinden. Een geïmporteerde hybride mismatch kan zich ook tussen hogere schakels in de keten voordoen en kan dan weer aanleiding geven tot een aftrekverbod in Nederland. Dit is overigens alleen aan de orde indien de hybride mismatch niet al door een aftrekverbod in de schakels tussen de BV en de hogere schakels (tussenschakels) wordt bestreden. Een dergelijk verbod is aan de orde indien een tussenschakel is gevestigd in een lidstaat van de EU. In die lidstaat zal immers eenzelfde bepaling gelden als art. 12ad Wet VPB 1969, omdat ATAD 2 ook door die lidstaat moet zijn geïmplementeerd. Dit laatste betekent overigens ook dat art. 12ad Wet VPB 1969 geen toepassing zal vinden als een hybride mismatch zich zou voordoen tussen twee schakels gevestigd in andere EU-lidstaten (dan Nederland). ATAD 2 werkt ook dan in de vorm van een bepaling zoals in Nederland opgenomen in art. 12aa Wet VPB 1969. Met andere woorden art. 12ad Wet VPB 1969 is alleen van toepassing bij een hybride mismatch tussen derde landen die niet door één van die landen wordt gerepareerd.

\subsection{Art. 12ae Wet VPB 1969}

In art. 12ae Wet VPB 1969 is een maatregel getroffen voor de situatie dat een lichaam voor de vennootschapsbelasting in Nederland is gevestigd, terwijl het voor de belastingwetgeving van een andere staat ook in die staat is gevestigd. Er is dan sprake van een dubbele vestigingsplaats (het betrokken lichaam wordt dan aangeduid als een dual resident company). Deze dubbele vestigingsplaats kan ertoe leiden dat dezelfde vergoeding, betaling of last, dan wel hetzelfde verlies, zowel in Nederland als in de andere staat in aftrek wordt genomen. In de praktijk wordt een dergelijke situatie vaak voorkomen als een belastingverdrag van toepassing is op het betrokken lichaam. Het verdrag zal er meestal in voorzien dat het lichaam uiteindelijk geacht wordt te zijn gevestigd in ofwel Nederland, ofwel de andere hiervoor bedoelde staat. In die situatie zal door de toewijzingsregels in het verdrag vervolgens worden voorkomen dat sprake is van dubbele aftrek. Ontbreekt een verdrag of voorziet het verdrag niet in een oplossing van de problematiek van een dubbele vestigingsplaats, dan is art. 12ae Wet VPB 1969 actueel. Gelet op de door Nederland gesloten verdragen lijkt art. 12ae Wet VPB 1969 voor Nederland echter van beperkte betekenis. Vermoedelijk is om die reden in de parlementaire geschiedenis maar weinig aandacht besteed aan deze figuur.

\subsection{Art. 12ab Wet VPB 1969}

In art. 12ab Wet VPB 1969 is de zogenoemde secundaire regel vastgelegd voor de situatie waarin een hybride mismatch leidt tot een aftrek zonder betrekking in de heffing die niet wordt bestreden in het land van de betaler (zoals in Nederland op basis van art. 12aa Wet VPB 1969 wel het geval is). Art. 12ab Wet VPB 1969 is bijvoorbeeld aan de orde indien een in Nederland gevestigde moeder, een bv, een vergoeding ontvangt van een entiteit die door Nederland als transparant wordt 
gezien, terwijl de entiteit in haar land van vestiging als niet-transparant wordt gezien. Als de entiteit een vergoeding betaalt aan de bv en deze in aftrek komt in het land van de entiteit, dan ontstaat een aftrek zonder betrekking in de heffing omdat de vergoeding in Nederland niet wordt waargenomen voor de heffing van de vennootschapsbelasting. Art. 12ab Wet VPB 1969 is nu van toepassing als het land van de entiteit de aftrek van de vergoeding niet verbiedt (zoals Nederland wel zou hebben gedaan op de voet van art. 12aa lid 1 onder e Wet VPB 1969). Nederland belast dus alsnog de vergoeding.

Het voorgaande kan worden geillustreerd met een voorbeeld. Hierbij is A Co het voor Nederland transparante lichaam en het voor land $\mathrm{X}$ niet-transparante lichaam. In de praktijk zal A Co de betaalde rente daadwerkelijk in aftrek willen brengen in land X. Daarvoor is dan winst nodig, die in dit geval wordt behaald door B Co, die in Nederland en land X niet als transparant geldt, maar waarmee $\mathrm{A}$ Co in land X wel een groepsregime is aangegaan. Dit regime maakt het dan mogelijk om de rente in land $\mathrm{X}$ in aftrek te brengen op in land $\mathrm{X}$ behaalde winst (zonder dat deze winst in Nederland in aanmerking wordt genomen).

\section{Voorbeeld 7}

\section{Figuur $4 \quad$ Mismatch-structuur met een buitenlands hybride lichaam}

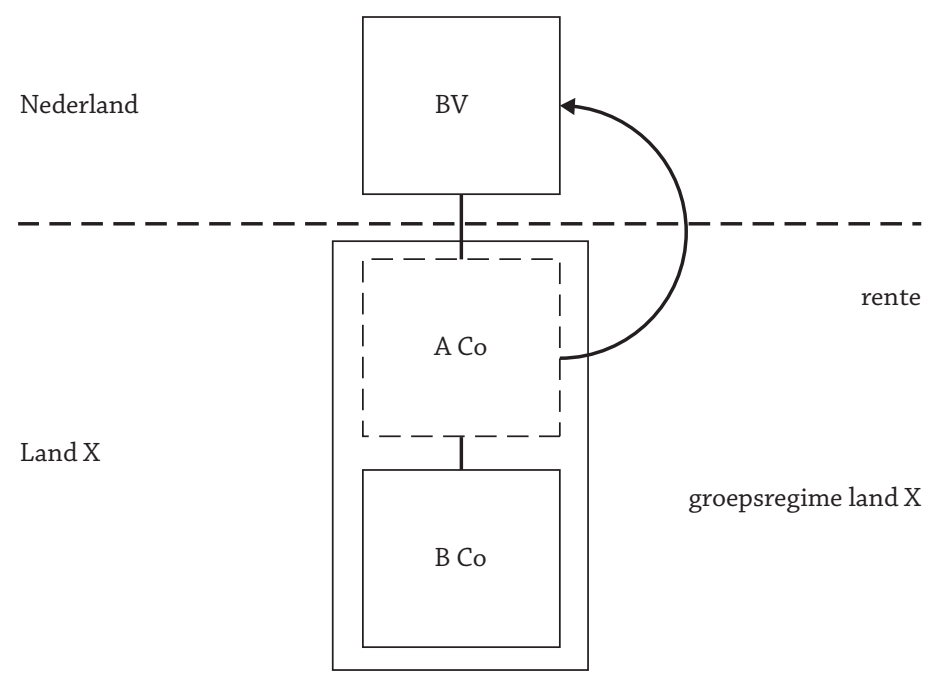

Art. 12ab Wet VPB 1969 is van toepassing op situaties waarvoor in Nederland de onderdelen a, b en e van art. 12aa lid 1 Wet VPB $1969^{17}$ zouden hebben gegolden indien de vergoeding haar oorsprong in Nederland zou hebben gehad. Dat betreft dus mismatches met hybride financiële instrumenten en hybride lichamen.

17 In art. 12ab lid 1 Wet VPB 1969 wordt ook verwezen naar de onderdelen c en $\mathrm{f}$ van art. 12aa lid 1 Wet VPB 1969. Deze bepalingen zijn hier niet aangehaald omdat zij zien op betalingen aan of door vaste inrichtingen en de problematiek van de hybride mismatches met vaste inrichtingen niet wordt besproken in deze bijdrage aan O\&F. 
Wetstechnisch is voor de secundaire regel in art. 12ab lid 3 Wet VPB 1969 vastgelegd dat Nederland geldt als de staat van de ontvanger van de vergoeding die in de heffing van de vennootschapsbelasting wordt betrokken. Deze voorziening is nodig omdat Nederland op basis van de gewone regels van de vennootschapsbelasting de vergoeding waarop art. 12ab Wet VPB 1969 doelt niet ziet of niet belast. Op basis van art. 12ac lid 1 Wet VPB 1969 wordt de staat van de ontvanger gedefinieerd als de staat die op grond van de wetgeving van een andere staat als ontvangende staat wordt aangemerkt. In voorbeeld 7 is de andere staat uit de vorige zin land X. Voor dat land is de betaling zichtbaar en vindt deze plaats aan de in Nederland gevestigde BV.

\section{Enkele begrippen}

\subsection{Inleiding}

In dit onderdeel wordt stilgestaan bij een aantal begrippen dat wordt gehanteerd bij de toepassing van de maatregelen tegen hybride mismatches.

\subsection{Gestructureerde regeling}

Een gestructureerde regeling doet zich voor als tussen niet met elkaar gelieerde partijen wordt geprofiteerd van een hybride mismatch. Een voorbeeld ${ }^{18}$ is aan de orde als een in Nederland gevestigde dochter via een niet-gelieerde partij leent van een buitenlandse moeder en tussen de niet-gelieerde partij en de Nederlandse dochter een lening wordt afgesloten die in Nederland anders wordt gekwalificeerd dan in het land waarin de niet-gelieerde partij is gevestigd.

\section{Voorbeeld 8}

\section{Figuur $5 \quad$ Gestructureerde regeling}

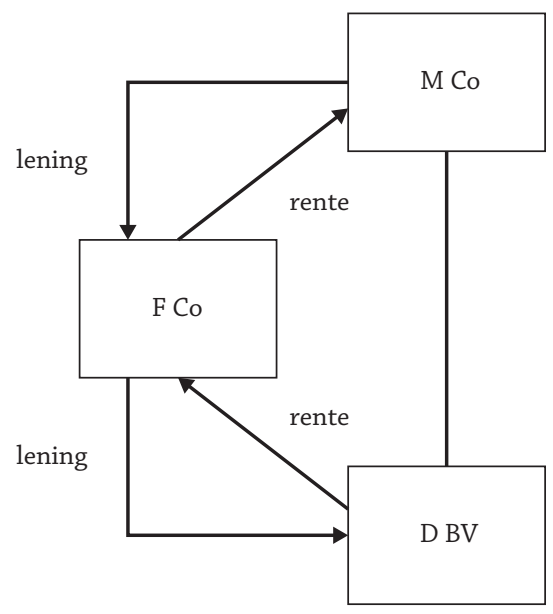


In het land van F Co wordt de lening aan D BV gezien als eigen vermogen, terwijl de lening in Nederland voor de vennootschapsbelasting als vreemd vermogen wordt aangemerkt. Het gevolg hiervan is dat D BV de rente in aftrek kan brengen, terwijl de rente bij F Co vrijgesteld is. Dit levert een voordeel op in de vorm van een belastingbesparing bij F Co. Als dit voordeel wordt gedeeld tussen F Co en $\mathrm{M}$ Co in de vorm van een hogere winst voor $\mathrm{F}$ Co en een hogere rente voor $\mathrm{M}$ Co dan onder normale omstandigheden gebruikelijk, dan is sprake van een gestructureerde overeenkomst. Dit beeld wordt versterkt als zou blijken dat de door F Co ontvangen rente lager is dan de rente die zij aan M Co moet betalen. Vóór belastingheffing zal dan sprake zijn van een nadeel met betrekking tot de vergoedingen over de leningen voor F Co. Door de fiscaliteit - het onbelast blijven van de ontvangen rente en de aftrekbaarheid van de betaalde rente - ontstaat dan zonder toepassing van een maatregel tegen hybride mismatches het voordeel voor de niet-gelieerde partijen M Co en D BV (enerzijds) en F Co (anderzijds). Voor D BV leidt vorenstaande situatie tot het niet aftrekbaar zijn van de rente die zij aan F Co moet betalen.

Van een gestructureerde regeling is geen sprake indien noch de belastingplichtige, noch een met hem gelieerde partij zich redelijkerwijs bewust heeft kunnen zijn van het voordeel behaald met de regeling en de belastingplichtige objectief bezien evenmin voordeel trekt uit het belastingvoordeel dat wordt behaald met de regeling. Dit betekent dat een lening aangegaan bij een niet-gelieerde bank niet als een gestructureerde regeling zal worden aangemerkt indien een pakket gebruikelijke voorwaarden, waaronder begrepen een gebruikelijke vergoeding, is overeengekomen en er geen gedetailleerde onderhandelingen over de structurering van de lening hebben plaatsgevonden. ${ }^{19}$

\subsection{Aftrek zonder betrekking in de heffing}

Zoals hiervoor bleek, kan een mismatch ontstaan indien sprake is van een 'aftrek zonder betrekking in de heffing'. In art. 12ac lid 1 onder a Wet VPB 1969 is vastgelegd dat van 'aftrek' sprake is indien een vergoeding - zonder toepassing van een regeling tegen mismatches - in mindering kan worden gebracht 'op de grondslag van een naar de winst geheven belasting'. Daarbij gaat het bij toepassing van de primaire regel om de Nederlandse vennootschapsbelasting en bij toepassing van de secundaire regel om een buitenlandse winstbelasting.

Voor wat betreft de woorden 'zonder betrekking in de heffing' kan worden opgemerkt dat dit zich voordoet indien de ontvanger niet belastingplichtig is (zoals de $\mathrm{cv}$ in de $\mathrm{cv} / \mathrm{bv}$-structuur). In de parlementaire geschiedenis ${ }^{20}$ wordt opgemerkt dat van een heffing evenmin sprake is als een vergoeding op basis van een andere kwalificatie van de vergoeding in aanmerking komt voor - zoals eerder vermeld een belastingvrijstelling, maar ook als voor de vergoeding recht bestaat op een gereduceerd tarief of een verrekening of teruggave van belasting (anders dan een 
bronbelasting ${ }^{21}$ ). De aanwezigheid van nog te verrekenen verliezen die ervoor zorgen dat niet hoeft te worden betaald over een overigens belaste vergoeding leidt echter niet tot een situatie waarin sprake is van het ontbreken van een heffing. ${ }^{22}$

In de parlementaire geschiedenis ${ }^{23}$ is uitvoerig aandacht besteed aan de vraag of wel sprake is van een betrekking in de heffing indien de ontvanger van een vergoeding een CFC-lichaam ${ }^{24}$ is. Onder een CFC-lichaam wordt een lichaam begrepen dat is gevestigd in een niet of laag belastend land (een 'belastingparadijs') en waarvan (bepaalde) voordelen op grond van hun aard worden toegerekend aan en belast bij een ander lichaam. Meestal is dit laatste lichaam de moedermaatschappij van het CFC-lichaam en wordt de moeder belast voor de rente, de royalty's en het dividend dat door het CFC-lichaam wordt genoten. Nederland kent onder meer in de vorm van art. 13ab Wet VPB 1969 een voorziening tegen het verschijnsel CFC-lichaam. Dit artikel resulteert erin dat bepaalde voordelen van een dergelijk lichaam bij de Nederlandse moeder van dit lichaam worden belast. De vraag is dus of de toepassing van een maatregel als art. 13ab Wet VPB 1969 ertoe leidt dat een vergoeding ontvangen door een CFC-lichaam - dat zelf niet of nauwelijks winstbelasting betaalt over deze vergoeding, maar waarbij de vergoeding wel bij een ander lichaam wordt belast - toch kan worden aangemerkt als te zijn betrokken in de heffing. De regering lijkt op dit punt streng: er lijkt uiteindelijk alleen sprake van een betrekken in de heffing indien de vergoeding bij het andere lichaam (de moeder van het CFC-lichaam) tegen het reguliere statutaire tarief wordt belast zonder dat daarbij enige tegemoetkoming wordt toegekend. ${ }^{25}$ Dat betekent dat een hybride mismatch met een CFC-lichaam tegelijkertijd kan worden getroffen door de maatregel tegen hybride mismatches en een maatregel die de voordelen van het gebruik van een CFC-lichaam moet tegengaan.

\subsection{Gelieerdheid}

In art. 12ac lid 2 Wet VPB 1969 is aangegeven wanneer er sprake is van een gelieerd lichaam. Daarvoor wordt in eerste aanleg verwezen naar art. 13ab lid 8 en 9 Wet VPB 1969. Er is dan wederzijds sprake van een gelieerd lichaam als een moeder een belang heeft van ten minste $25 \%$ in een dochter. Bovendien zijn zustermaatschappijen met elkaar gelieerd indien een gezamenlijke aandeelhouder een belang van ten minste $25 \%$ houdt in deze maatschappijen. Om te voorkomen dat

21 De woorden 'anders dan een bronbelasting' zien op de verrekening of teruggave van belasting. Een voorbeeld van een bronbelasting is in Nederland de dividendbelasting. De dividendbelasting is een voorheffing op de inkomstenbelasting respectievelijk de vennootschapsbelasting en wordt daarmee verrekend. Het buitenland kent ook bronheffingen op rente en royalty's. Nederland zal met ingang van 2021 een geconditioneerde bronheffing op rente en royalty's invoeren. Zie de wet van 18 december 2019, Stb. 2019, 513.

22 Kamerstukken II 2018/19, 35241, nr. 3, p. 59.

23 Kamerstukken II 2018/19, 35241, nr. 3, p. 59 en 60, Kamerstukken II 2019/20, 35241, nr. 7, p. 29 en 30, Kamerstukken I 2019/20, 35241, C, p. 5 en 6, en Kamerstukken I 2019/20, 35241, E, p. 7 en 9.

$24 \mathrm{CFC}=$ Controlled Foreign Company.

25 Kamerstukken I 2019/20, 35241, E, p. 7 en 9. 
een aandeelhouder zijn belang van ten minste $25 \%$ gaat spreiden over verschillende aandeelhouders - om daarmee onder de $25 \%$-grens te blijven - is er bovendien voor gekozen om ook aandeelhouders die onderdeel zijn van een zogenoemde samenwerkende groep in de zin van art. 10a lid 6 Wet VPB 1969 en die gezamenlijk een belang van ten minste $25 \%$ aanhouden in een of meer lichamen zoals hiervoor bedoeld, als gelieerde lichamen aan te merken. Deze uitbreiding kan investerings- en beleggingsstructuren raken. Ten slotte is er sprake van een gelieerd lichaam indien een belastingplichtige met een ander lichaam onderdeel is van een groep als bedoeld in art. 2:24b BW.

Zoals aangegeven vindt bestrijding van hybride mismatches doorgaans alleen plaats in gelieerde verhoudingen. Bij de meeste figuren die in art. 12aa lid 1 Wet VPB 1969 aan de orde zijn, is eenvoudig vast te stellen of sprake is van gelieerde verhoudingen. Met betrekking tot de figuur die wordt bestreden in onderdeel $b$ van deze bepaling is in de parlementaire behandeling ${ }^{26}$ evenwel nog extra duidelijkheid geschapen. Het gaat dan om de structuur waarbij een of meer participanten via een naar Nederlandse begrippen transparant lichaam een belang in een bv of soortgelijke vennootschap houden (bijvoorbeeld de $\mathrm{cv} / \mathrm{bv}$-structuur). In dat geval is er voor de toepassing van art. 12aa lid 1 onder b Wet VPB 1969 alleen sprake van gelieerdheid indien een participant door middel van het transparante lichaam ten minste een belang van $25 \%$ houdt in de bv. De participant kan ook een samenwerkende groep zijn als hiervoor bedoeld.

\section{De documentatieverplichting}

In art. 12ag Wet VPB 1969 is de documentatieverplichting opgenomen die behoort bij de maatregelen die zijn getroffen tegen hybride mismatches. In het eerste lid is de kern van de documentatieverplichting opgenomen. Dit luidt: 'Een belastingplichtige neemt in zijn administratie gegevens op waaruit blijkt in hoeverre en op welke wijze ten aanzien van een vergoeding, betaling, veronderstelde betaling, last of verlies deze afdeling ${ }^{27}$ met betrekking tot een jaar van toepassing is.' Zoals uit de aangehaalde tekst blijkt, is de documentatieverplichting verstrekkend. Voor iedere vergoeding enzovoort moet worden bijgehouden of deze wel of niet onder de hybride-mismatchmaatregelen valt. Indien de maatregelen wel van toepassing zijn, moet vervolgens uit de administratie blijken op welke manier die regels zijn toegepast. Zijn deze regels volgens de belastingplichtige niet van toepassing, dan moet dit eveneens blijken uit gegevens die zijn opgeslagen in de administratie. ${ }^{28}$

In de parlementaire geschiedenis ${ }^{29}$ zijn handreikingen gedaan met betrekking tot de informatie die moet worden aangehouden. Zo wordt opgemerkt dat kan

26 Kamerstukken I 2019/20, 35241, nr. 7, p. 35.

27 Bedoeld is afd. 2.2A Wet VPB 1969, waarin de maatregelen tegen hybride mismatches zijn opgenomen.

28 Kamerstukken II 2018/19, 35241, nr. 3, p. 73 en 74.

29 Kamerstukken II 2018/19, 35241, nr. 3, p. 28. 
worden gedacht aan de aanwezigheid van een wereldwijd concernschema (bijvoorbeeld om vast te stellen of een vergoeding al dan niet betaald wordt aan een gelieerde partij). Verder kan een beoordeling van de gebruikte financiële instrumenten of hybride lichamen in de administratie van de belastingplichtige zijn opgenomen (waaruit dan moet blijken hoe deze in het betrokken buitenland fiscaal worden behandeld). Indien de hybride-mismatchmaatregelen vervolgens worden toegepast, moet bovendien worden gedacht aan een gemotiveerde berekening van de aftrekbeperking. Later in de parlementaire geschiedenis ${ }^{30}$ is daaraan toegevoegd dat ook buitenlandse belastingaangiftes of -aanslagen van betekenis kunnen zijn als deze inzicht geven in de fiscale behandeling van financiële instrumenten en hybride lichamen. Voorts kunnen opinies van deskundigen over de relevante buitenlandse rechtsgebieden worden gebruikt voor het nakomen van de documentatieverplichting.

De documentatieplicht van art. 12ag Wet VPB 1969 geldt in beginsel voor alle aan de vennootschapsbelasting onderworpen belastingplichtigen. Daarmee lijkt een forse administratieve lastenverzwaring te ontstaan. De regering heeft daarom gepoogd het effect van de documentatieplicht enigszins te relativeren. Zo stelt $\mathrm{zij}^{31}$ dat een belastingplichtige die deel is van een concern dat alleen nationaal opereert en geen internationale betalingen doet aan of ontvangt van gelieerde partijen, kan volstaan met het noteren van dit gegeven om buiten het bereik van de hybride-mismatchregels te blijven. Het zou dan gaan om circa $81 \%$ van de belastingplichtigen voor de vennootschapsbelasting (circa 603.000 belastingplichtigen). Voor de belastingplichtigen die behoren tot een internationale groep (circa 137.000) verwacht de regering dat het merendeel slechts met een verwaarloosbare administratieve lastenverzwaring te maken zal krijgen, omdat al gauw zal blijken dat geen hybride elementen in de betalingen aan of van buitenlandse leden van dezelfde groep aanwezig zullen zijn. De aandacht bij de internationale groep gaat vooral uit naar de ongeveer 40.000 belastingplichtigen met een directe buitenlandse moeder of dochter. Ook binnen die groep zal uiteindelijk maar een beperkt aantal belastingplichtigen te maken krijgen met een serieuze administratieve lastenverzwaring, aldus de regering. ${ }^{32}$

Wordt niet aan de documentatieverplichting voldaan ${ }^{33}$ en heeft de inspecteur het vermoeden dat toepassing van de maatregelen tegen hybride mismatches moet plaatsvinden, dan kan de bewijslast worden omgekeerd en verzwaard (art. 12ag lid 2 Wet VPB 1969). Treedt dat - na het opvragen van informatie door de inspecteur - in, dan zal de belastingplichtige moeten doen blijken dat de maatregelen tegen hybride mismatches niet van toepassing zijn. Normaliter zal het bewijs daarvan op de inspecteur drukken, omdat het niet in aftrek brengen van een ver-

30 Kamerstukken II 2019/20, 35241, nr. 7, p. 21.

31 Kamerstukken II 2018/19, 35241, nr. 3, p. 28 en 29, Kamerstukken II 2019/20, 35241, nr. 7, p. 21 en Kamerstukken I 2019/20, 35241, C, p. 8.

32 Kamerstukken II 2019/20, 35241, nr. 7, p. 21.

33 Als de Belastingdienst gegevens opvraagt, zal hij de belastingplichtige eerst een redelijke termijn - ten minste een periode van zes weken - geven om te voldoen aan de documentatieverplichting. 
schuldigde vergoeding (de primaire regel) respectievelijk het belasten van een vergoeding (de secundaire regel) op de voet van art. 12aa of 12ab Wet VPB 1969 leidt tot een verhoging van de winst van de belastingplichtige. Wordt de bewijslast omgekeerd, dan zal de aftrekbaarheid respectievelijk de niet-belastbaarheid van de vergoeding dus door de belastingplichtige moeten worden bewezen. Omdat deze bewijslast is verzwaard, zal hij dit overtuigend moeten doen. ${ }^{34}$

In dit verband wordt aan de belastingplichtige niet de mogelijkheid geboden om vooraf te laten toetsen of de inspecteur terecht de bewijslast heeft omgekeerd en verzwaard. Een dergelijke mogelijkheid bestaat wel bij de algemene administratieverplichting van art. 52 van de Algemene wet inzake rijksbelastingen (AWR) voor onder meer ondernemers. Tegen de informatiebeschikking die de inspecteur oplegt indien de administratie van de belastingplichtige niet voldoet aan de normen van art. 52 AWR kan de belastingplichtige in bezwaar en beroep komen. Hij kan dus door de rechter laten toetsen of zijn administratie niet in orde is. Omkering van de bewijslast ${ }^{35}$ volgt dan pas als na deze toetsing definitief komt vast te staan dat de belastingplichtige niet aan de administratieverplichting van art. $52 \mathrm{AWR}$ voldoet.

\section{Opbrengst van de maatregel}

In de parlementaire geschiedenis ${ }^{36}$ is de verwachting uitgesproken dat per saldo geen opbrengst van de maatregel tegen hybride mismatches valt te verwachten. Dat lijkt aannemelijk omdat belastingplichtigen ernaar zullen streven de aftrek van vergoedingen enzovoort als bedoeld in art. 12aa Wet VPB 1969 in Nederland veilig te stellen. Daarvoor zullen zij de hybride structuur op grond waarvan geen betrekking in de heffing dan wel dubbele aftrek kon worden bereikt inmiddels hebben beëindigd. Daar waar deze structuren toch nog voortbestaan, kan een kleine opbrengst worden verwacht. Daar staat evenwel tegenover, aldus de parlementaire toelichting, dat door het weghalen van een complete $\mathrm{cv} / \mathrm{bv}$-structuur de winst die meestal toch nog in Nederland te noteren en te belasten viel, zal verdwijnen. Per saldo wordt verwacht dat deze laatste twee posten tegen elkaar wegvallen, zodat ook daaruit geen opbrengst te verwachten is.

\section{Afronding}

Bij de uitvoerbaarheid van de Wet ATAD 2 vallen de nodige kanttekening te plaatsen. Hierna plaats ik er ook enkele zonder de indruk te willen wekken volledig te zijn.

34 Omkering en verzwaring van de bewijslast is dus de sanctie waarmee de belastingplichtige te maken krijgt als hij niet voldoet aan de documentatieverplichting. In uitzonderlijke gevallen kan daaraan bovendien nog een strafrechtelijke sanctie worden verbonden (art. 68 AWR).

36 Kamerstukken II 2018/19, 35241, nr. 3, p. 34 en Kamerstukken II 2019/20, 35241, nr. 7, p. 26. 
1. De wetgever is bij de codificatie van ATAD 2 meestal in de buurt gebleven van de richtlijn en de opvattingen van de OESO zoals neergelegd in BEPS Action 2. Soms is voor een strengere aanpak gekozen, zoals door:

- de invoering van de documentatieverplichting;

- het aannemen van gelieerdheid bij de toepassing van art. 12aa lid 1 onder b, e en $g$ Wet VPB 1969 bij een belang van ten minste 25\% in plaats van 50\% zoals in ATAD 2; 37

- het niet toepassen van een uitzondering voor hybride overdrachten uitgevoerd door financieel handelaren; ${ }^{38}$

- het niet toepassen van een tijdelijke uitzondering voor banken van door deze gehanteerde hybride financiële instrumenten; ${ }^{39}$ en

- het soms niet buiten toepassing laten van de secundaire regel. ${ }^{40}$

Op zich lijkt de strengere aanpak - wellicht behoudens de documentatieverplichting - niet erg veel consequenties te hebben. In de parlementaire geschiedenis ${ }^{41}$ wordt het effect daarvan dan ook gerelativeerd. Toch is het niet zo betrekkelijk als het lijkt. De 'strenger dan nodig'-aanpak is een trend die ook bij de implementatie van andere fiscale EU-richtlijnen ${ }^{42}$ plaatsvindt en die door andere EU-lidstaten vaak niet wordt gevolgd. In het huidige Nederlandse politieke klimaat is dat wellicht verklaarbaar, maar het is niet ondenkbaar dat daardoor de uitvoering van al deze maatregelen ook wordt verzwaard. Daar komt bovendien nog bij dat deze aanpak de reputatie van Nederland als aantrekkelijke vestigingsstaat voor buitenlandse investeerders vermoedelijk niet verbetert (als blijkt dat buurlanden minder ver gaan).

2. In de uitvoerbaarheidstoets die onderdeel uitmaakt van de parlementaire geschiedenis van de Wet ATAD $2^{43}$ wordt weliswaar als eindoordeel gegeven dat de wet uitvoerbaar is, maar het commentaar onder het kopje 'Handhaafbaarheid' klinkt toch aanzienlijk minder optimistisch:

'Het huidige wetsvoorstel behelst zeer complexe materie en er wordt bovendien geen voor de Nederlandse uitvoeringspraktijk duidelijk begrippenkader gehanteerd. Daarnaast kan de samenloop met andere regelingen in de Wet $\mathrm{Vpb}$, alsmede de implementatie van deze richtlijn in andere landen, tot onduidelijke situaties leiden en de uitvoering van dit wetsvoorstel compliceren.

Cruciale informatie, voor de beoordeling of ATAD2 van toepassing is, zit in het buitenland. Er is sprake van een informatie-asymmetrie. Hierdoor kan de

41 Kamerstukken II 2019/20, 35241, nr. 7, p. 28 en 29.

42 Vgl. bijv. de implementatie van enkele maatregelen uit ATAD 1. In het bijzonder de renteaftrekbeperking van art. 4 ATAD vond in Nederland strenger plaats dan in de meeste buurlanden.

43 Bijlage bij Kamerstukken II 2018/19, 35241, nr. 3 (https://zoek.officielebekendmakingen.nl/ dossier/35241). 
Belastingdienst niet het gewenste toezicht uitoefenen en wordt het risico op fraude vergroot. De documentatieverplichting, evenals de omkering van bewijslast bij het niet tijdig verstrekken van de documentatie dragen bij aan het versterken van de informatiepositie van de Belastingdienst en daarmee aan de handhaving bij belastingplichtigen die deze maatregelen niet willen naleven. De documentatieverplichting draagt echter niet bij aan de detectie van risicogevallen. Detectie zal plaatsvinden op basis van concrete signalen (vooroverleg, controles, bedrijfsgesprekken, (internationale) gegevensuitwisseling etc.).'

Ook het oordeel over de fraudebestendigheid is kritisch: '[V]anwege de informatie-asymmetrie en de onduidelijkheid over het begrippenkader biedt het huidige voorstel ruimte om (desgewenst) deze bepaling te ontduiken.'

Deze commentaren stemmen dus niet optimistisch. Afgezien van de ingewikkeldheid van de regelgeving is een belangrijke achilleshiel van de Wet ATAD 2 dat de informatie nodig voor de toepassing van de regelgeving zich in het buitenland bevindt. Dat is voor de Belastingdienst lastig. Overigens is het de vraag of de internationale informatie-uitwisseling tussen de betrokken belastingautoriteiten waarnaar wordt verwezen veel soelaas zal bieden. In de verhouding met de staten waarmee uitwisseling van informatie is overeengekomen, ${ }^{44}$ zal het wellicht nog meevallen, maar of daar veel staten onder vallen waarmee hybride mismatches ontstaan, is twijfelachtig.

3. Zoals aangegeven in het begin van deze paragraaf verplicht ATAD 2 niet tot de documentatieverplichting zoals neergelegd in art. 12ag Wet VPB 1969. ${ }^{45}$ De regering ${ }^{46}$ rechtvaardigt de verplichting door erop te wijzen dat de maatregelen tegen hybride mismatches zonder toepassing van de documentatieverplichting niet uitvoerbaar zijn. Hoewel deze rechtvaardiging op het eerste gezicht aannemelijk klinkt en de regering - zoals hiervoor vermeld - het nationaal opererende bedrijfsleven praktisch gesproken buiten de documentatieplicht houdt als geen internationale betalingen zijn gedaan, wordt het internationaal opererende bedrijfsleven toch wel met een stevige administratieve lastenverzwaring geconfronteerd. De documentatieplicht van art. 12ag Wet VPB 1969 gaat, anders dan de regering suggereert, echt verder dan de eerdergenoemde algemeen geldende administratieverplichting van art. 52 AWR, zoals deze in de praktijk wordt toegepast. Als voorbeeld kunnen de eerdergenoemde rechtskundige analyses van financiële instrumenten en lichamen naar Nederlands en buitenlands fiscaal recht (waaronder belastingadviezen) worden genoemd. Deze vallen buiten de administratieverplichting van art. 52 AWR.

44 Zie de Wet op de internationale bijstandsverlening bij de heffing van belastingen (wet van 24 april 1986, Stb. 1986, 249).

45 Kamerstukken II 2019/20, 35241, nr. 7, p. 20.

46 Kamerstukken II 2018/19, 35241, nr. 3, p. 29. 
De vraag is of de documentatieplicht in redelijkheid kan worden nageleefd. Naar het oordeel van de regering ${ }^{47}$ zijn daarvoor voldoende waarborgen ingebouwd. Allereerst voert zij aan dat de belastingplichtige een redelijke termijn wordt gegund voor het aanleveren van de documentatie als deze wordt opgevraagd. De tweede waarborg is dat omkering en verzwaring van de bewijslast bij het niet nakomen van de documentatieverplichting alleen mogelijk is indien de inspecteur zijn vermoeden kan onderbouwen dat de maatregelen tegen hybride mismatches van toepassing zijn. Als derde waarborg geldt, aldus de regering, dat omkering van de bewijslast niet plaatsvindt indien de belastingplichtige door overmacht niet kan voldoen aan de documentatieverplichting. Dit is bijvoorbeeld aan de orde bij een gestructureerde regeling of - onder omstandigheden - als een transactie is aangegaan met een gelieerde partij waarin een minderheidsbelang wordt aangehouden. Als vierde waarborg geldt dat de inspecteur ook bij omkering en verzwaring van de bewijslast evenredig moet handelen. Ten slotte kan tijdens een bezwaar- en beroepsprocedure de omkering en verzwaring van de bewijslast worden getoetst.

Op papier lijkt daarmee de rechtsbescherming van belastingplichtigen inderdaad een flink eind gewaarborgd. Toch zijn enkele kanttekeningen mogelijk. Het is namelijk niet zo dat het verzamelen van documentatie door de belastingplichtige een eenmalige inspanning is die pas aan de orde is indien de Belastingdienst de documentatie opvraagt. Belastingplichtigen die internationaal gelieerd en actief zijn, zullen vanaf 2020 steeds een ATAD 2-dossier moeten opbouwen en bijhouden, zodat dat desgevraagd kan worden ingezien door de Belastingdienst. Dat vergt een continue inspanning. Daarbij komt dat de derde waarborg maar in een beperkt aantal gevallen een rol zal spelen, terwijl de vierde waarborg lijkt te overlappen met de laatste waarborg.

De taxatie van de regering in de parlementaire geschiedenis ${ }^{48}$ is dat de administratieve lasten voor het bedrijfsleven op jaarbasis met $€ 3$ miljoen structureel zullen toenemen. De regering gaat ervan uit dat de eerdergenoemde groep van 40.000 belastingplichtigen gemiddeld genomen niet meer dan een uur per jaar bezig zal zijn met de documentatieverplichting en berekent de kosten van dit uur op $€ 80$. Mede gelet op het feit dat niet alleen rentebetalingen aan gelieerde buitenlandse partijen, maar ook andere betalingen (bijvoorbeeld voor goederen en diensten afkomstig van dergelijke partijen) moeten worden gedocumenteerd, ${ }^{49}$ lijkt deze schatting - op zijn vriendelijkst geformuleerd - niet meer dan een slag in de lucht.

4. Zoals hiervoor aangegeven, kunnen de maatregelen tegen hybride mismatches en CFC-regelgeving tegelijkertijd van toepassing zijn, met als consequentie dat in feite dubbele heffing optreedt. Dat kan als overkill worden getypeerd. Het is jammer dat de wetgever voor deze situatie geen mogelijkheid ziet om dubbele heffing 
te voorkomen. Het dreigt de laatste tijd in de fiscaliteit een trend te worden om overkill op de koop toe te nemen (of soms bewust na te streven). ${ }^{50}$ Samenloop kan zich ook voordoen met de nieuw in te voeren Wet bronbelasting 2021, die voorziet in een belasting over vanuit Nederland uitgekeerde rente en royalty's naar laag- of niet-belastende jurisdicties. In de fiscale literatuur ${ }^{51}$ is hier aandacht voor gevraagd en het lijkt inderdaad wenselijk ook dit effect nader te bekijken.

5. Ten slotte. Na het voorgaande is het wel duidelijk dat het bij de Wet ATAD 2 om complexe regelgeving gaat. Het is ook voor fiscalisten 'stevige kost'. Bij alle kritiek die mogelijk is - en die hiervoor ook voor een deel is gespuid - moet worden bedacht dat de wetgever maar beperkt de vrije hand heeft gehad bij het redigeren van deze regelgeving. Daarbij moet niet alleen worden gedacht aan het feit dat de wetgever trouw diende te blijven aan ATAD 2 (de richtlijn), maar ook aan het feit dat de praktijk van internationaal van elkaar verschillende belastingstelsels weinig manoeuvreerruimte liet aan de wetgever. Die verschillen opheffen zou beter zijn, maar dat kan de Nederlandse wetgever niet in z'n eentje. Het is zo bezien eigenlijk al een wonder dat er internationaal zoveel overeenstemming is bereikt dat ATAD 2 er heeft kunnen komen. 